\title{
Evaluation of the geotouristic attractions from the Wojcieszów area
}

\section{Ocena walorów geoturystycznych okolic Wojcieszowa}

\author{
Jolanta Muszer ${ }^{1 *}$, Antoni Muszer² \\ 1,2 University of Wrocław, Faculty of Earth Sciences and Environmental Management, \\ Institute of Geological Sciences; pl. M. Borna 9, 50-205 Wrocław;
}

'jolanta.muszer@uwr.edu.pl; 2antoni.muszer@uwr.edu.pl

\section{* Corresponding Author}
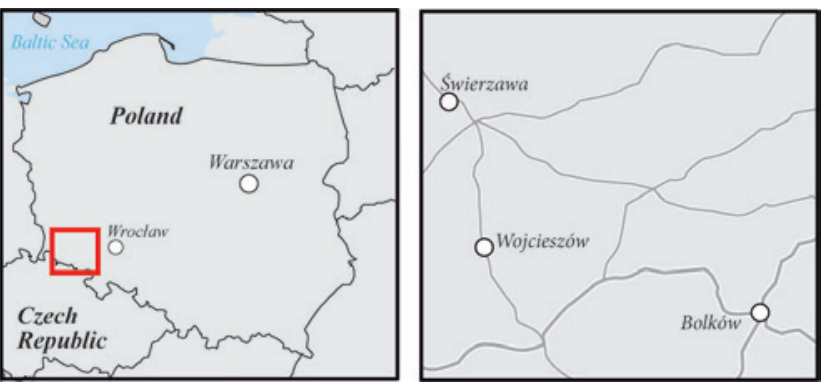

Article history:

Received: 6 July 2017

Accepted: 14 November 2017

Available online: 20 June 2018

(C) 2017 Authors. This is an open access publication, which can be used, distributed and reproduced in any medium according to the Creative Commons CC-BY 4.0 License requiring that the original work has been properly cited.

\begin{abstract}
The paper presents the results of geological and landscape studies in the Wojcieszów area (the Kaczawskie Mountains), which include investigation, inventory, documentation and a first evaluation of its geotourism objects. This area has high values of the natural environment and a rich geodiversity associated with a complicated geological structure (the Kaczawa unit, the metamorphic Kaczawa Complex). Some of the anthropogenic activities (mining), which have revealed interesting fragments of the geological structure, have also influenced the increase of geotourism attractions in this area. The area is one of the best examples of the region in the Sudetes, where economic considerations predominate over the protection of the natural environment. Since the $16^{\text {th }}$ century, the crystalline Wojcieszów limestone was mined in numerous quarries (e.g. Silesia, Gruszka, Połom, Miłek). In the limestone, intensive karst processes occurred mainly in the Paleogene (numerous caves and speleothems). As a result of economic activity, some of the caves had been permanently destroyed and the former "Polom" nature reserve was liquidated in the late 1970s. Currently, the only nature reserve is the "Góra Milek in Wojcieszów". The area around Wojcieszów is rich in numerous quarries, where other construction materials were obtained (e.g. phyllites, greenschists, metarhyodacites). Since the 12th to 20th centuries, copper ore was also exploited (adits and shafts) in the Żeleźniak massif (east of Wojcieszów in the Radzimowice area). In the 20th century, uranium ore was sought at the Chmielarz Hill adit. Recently, the Cambrian limestones (Połom) and Quaternary deposits (Okrajnik, Stara Kraśnica) have been exploited. Paradoxically, economic activity, which caused destruction of some protected objects, has also enriched the geodiversity of the Wojcieszów region. The results of the evaluation proved the significant geotouristic potential of the studied area. The most attractive geosites around Wojcieszów demonstrate typical lithologies of the Kaczawa Succession and depict the pre-Variscan geological evolution of the area.
\end{abstract}

Key words: Western Sudetes, Kaczawa metamorphic unit, geotourism potential, geosites, mining heritage sites, evaluation

Treść: W artykule przedstawiono wyniki badań geologicznych i krajobrazowych rejonu Wojcieszowa (Góry Kaczawskie), które obejmowaty inwentaryzację, dokumentację i pierwsza waloryzację jego obiektów geoturystycznych. Obszar ten jest cenny pod względem przyrodniczym oraz charakteryzuje się bogata georóżnorodnościa, związana ze skomplikowana budowa geologiczna (metamorfik kaczawski, kompleks kaczawski). Na wzrost walorów geoturystycznych tego obszaru wplynęty też niektóre działania antropogeniczne (górnictwo), które odstonity ciekawe fragmenty budowy geologicznej. Okolice Wojcieszowa stanowia jeden z najlepszych w Sudetach przykładów regionu, w którym względy gospodarcze przeważają nad ochrona przyrody. Już w XVI wieku zaczęto w okolicy wydobywać wapień krystaliczny zwany wojcieszowskim, odsłonięty w licznych kamieniołomach (np. Silesia, Gruszka, Połom, Miłek). Wwapieniach 
przebiegaty intensywne procesy krasowe, które zachodzity głównie w paleogenie (bardzo liczne jaskinie, szata naciekowa). Na skutek działalności gospodarczej część jaskiń została bezpowrotnie zniszczona, a dawny rezerwat przyrody "Góra Połom” został zlikwidowany pod koniec lat 70. Obecnie jedynym rezerwatem jest "Góra Miłek” w Wojcieszowie. W okolicach Wojcieszowa wystepuja liczne łomy, w których pozyskiwano inne surowce budowlane (m.in. fyllity, zieleńce, metaryodacyty). Od XII do XX wieku w masywie Żeleźniaka (na wschód od Wojcieszowa w rejonie Radzimowic) eksploatowano również rudy miedzi (sztolnie i hałdy). WXX wieku poszukiwano rud uranu (sztolnia na Chmielarzu). Wspótcześnie eksploatowane są kambryjskie wapienie (Połom) oraz osady czwartorzędowe (Okrajnik, Stara Kraśnica). Paradoksalnie, działalność gospodarcza, niszcząc niektóre obiekty chronione, jednocześnie wptynęła pozytywnie na wzrost georóżnorodności w rejonie Wojcieszowa. Wyniki ewaluacji udowodnity znaczacy potencjat geoturystyczny badanego obszaru. Zaproponowano najbardziej atrakcyjne obiekty geoturystyczne okolic Wojcieszowa, przedstawiajace litologię dolnej części sukcesji kaczawskiej i ukazujące przedwaryscyjska ewolucję tego obszaru.

Stowa kluczowe: Sudety Zachodnie, metamorfik kaczawski, potencjał geoturystyczny geostanowiska, obiekty dziedzictwa górniczego, waloryzacja

\section{Introduction}

The Kaczawskie Mts. and Kaczawa Foothill represent one of the "first-rate" regions of the Sudetes with highest geotouristic values and best developed infrastructure (see Rogowski, 2016). There are some publications, which present its geotouristic values, potential and possibilities of geotouristic development (e.g. Pijet-Migoń \& Migoń, 2009; Migoń \& Pijet-Migoń, 2010; Migoń, 2014). This region is known mainly for the Palaeozoic and the Cenozoic volcanism (the Land of Extinct Volcanoes) and some mining objects (Goldmine "Aurelia" and gold museum in Złotoryja, open-air museum of mining and metallurgy in Leszczyna). In addition, some cyclical events are offered for tourists (e.g. Agate Summer in Lwówek, the International Gold Panning in Złotoryja). There are eleven educational paths and two tourist trails (Rogowski, 2016). Against this background, the Wojcieszów sub-region remains underrated in terms of tourism.

The Wojcieszów sub-region has been for a long time an interesting area for many researchers, not only because of its various geological structure (e.g. Gürich, 1929; Schwarzbach, 1939; Gunia, 1967; Baranowski \& Lorenc, 1978, 1981; Lorenc, 1983; Baranowski et al., 1990; Cwojdziński \& Kozdrój, 1994; Cymerman, 2002; Kryza et al., 1990; Kryza, Muszyński, 1992, 2003; Białek et al., 2007), but also because of the importance of rock raw materials (Manecki \& Młodożeniec, 1959, 1960; Manecki, 1962, 1963, 1965; Dziekoński, 1972; Holeczek \& Janeczek, 1991; Siuda, 2001, 2002, 2003, 2004; Mikulski, 2005, 2007; Madziarz, 2009). In recent years, several papers on geotourism potential and the geotourism attractiveness of this area have been published (Kryza 2008; Mianowicz \& Brzozowska, 2009; Łodziński et al., 2009; Różycka, 2014), but an evaluation of its geosites has not been carried out. Inventory and evaluation of geosites is required for the proper use of georesources of the region.
The aim of this paper is to present the results of geoattraction studies in the vicinity of Wojcieszów and their connection with the exploitation of rock raw materials and nature protection. Fieldworks were prepared in the years 2008-2011, during the research project "The Sudetic Geostrada - geological and landscape studies heritage with an inventory of the objects of abiotic nature" (see Bartuś et al., 2009; Łodziński et al., 2009; Słomka et al., 2009). The project included documentation of the diversity of landforms, the complexity of geological structures, the geological-mining heritage and abiotic nature in selected parts of the Sudetes. The Wojcieszów area belongs to the western sector of the Sudetic Geostrada. The main aim of the project was to popularize geotourism to improve the tourist industry in the region. The concept of geotourism is closely related to the concept of geoconservation, which means "protection of geodiversity for the regard of its intrinsic ecological value and geological heritage" (see Sharples, 2002).

Economic development often takes place at the expense of the natural environment (see Redclif, 1992). This conflict is therefore inherent in the development of civilization. Kassenberg and Marek (1986) presented a classification of conflicts from the point of view of both location and values that the conflict arises in (see Kistowski, 1996). These authors have distinguished overlapping (where resources and values occur in the same area) and neighborhood conflicts (where the use of resources in a particular area restricts the use of neighboring areas).

Until the 1989, in Poland, the exploitation of all available resources took place, but only occasional forms of conservation were introduced (Otok, 1990). Recent requirements, concerning plans of spatial development in Poland, include the recognition and respect for the values of the natural environment. They also seek to improve the environment, especially in regions where it has been neglected for many years. 


\section{Methodology}

Selected objects of geoheritage in the Wojcieszów area were examined as potential sites or site-sets for geotourism. The field works included inventory, photographic documentation, topography and basic geological investigation of geosites located in the $10 \mathrm{~km}$ zone, on both sides of the main trail of the Sudetic Geostrada (the Geostrada belt). Geographic coordinates and elevation of geosites also were determined. Each geosite was classified into one of the categories: e.g. active quarry, closed quarry, natural outcrop, rock, cave, gravel-mine, adit, shaft, heap, lime kiln, spring (see Tab. 1).

The valuation class method was used to estimate all geosites of the Sudetic Geostrada. Evaluation of the geosites was the sum of six criteria, which include: scientific value (1-5 pts.), educational value (1-5 pts.), degree of conservation (1-5 pts.), position relative to the hiking trails (1-3 pts.), availability (1-5 pts.) and the overall attractiveness of tourist facilities (1-5 pts.) (see Słomka et al., 2009; Bartuś, 2015). In total, fifty nine geosites in the Wojcieszów area were catalogued and valorized and the most attractive objects are presented in Table 1.

Tab. 1. The most attractive geosites in the vicinity of Wojcieszów and their evaluation

\begin{tabular}{|c|c|c|c|c|c|c|c|c|c|}
\hline No & Geosite name & $\begin{array}{c}\text { Geosite } \\
\text { type }\end{array}$ & $\begin{array}{c}\text { Scientific } \\
\text { value } \\
\text { (1-5 pts.) }\end{array}$ & $\begin{array}{c}\text { Educa- } \\
\text { tional } \\
\text { value } \\
\text { (1-5 pts.) }\end{array}$ & $\begin{array}{c}\text { Degree } \\
\text { of con- } \\
\text { servation } \\
(1-5 \text { pts. })\end{array}$ & $\begin{array}{l}\text { Position } \\
\text { relative } \\
\text { to the } \\
\text { hiking } \\
\text { trails } \\
\text { (1-3 pts. })\end{array}$ & $\begin{array}{c}\text { Avail- } \\
\text { ability } \\
\text { (1-5 pts.) }\end{array}$ & 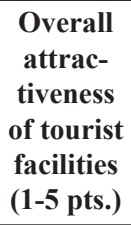 & Total \\
\hline 1 & The marble quarry Silesia in Wojcieszów & $\begin{array}{l}\text { closed } \\
\text { quarry }\end{array}$ & 5 & 5 & 5 & 3 & 5 & 5 & 28 \\
\hline 2 & The marble quarry Gruszka in Wojcieszów & $\begin{array}{l}\text { closed } \\
\text { quarry }\end{array}$ & 5 & 5 & 5 & 3 & 5 & 4 & 27 \\
\hline 3 & $\begin{array}{l}\text { The marble quarry at the Połom Hill in } \\
\text { Wojcieszów }\end{array}$ & $\begin{array}{l}\text { active } \\
\text { quarry }\end{array}$ & 5 & 5 & 5 & 2 & 3 & 5 & 25 \\
\hline 4 & Lisie Skały - Fox Rocks in Wojcieszów & rocks & 5 & 4 & 4 & 3 & 4 & 3 & 23 \\
\hline 5 & Biały Kamień -White Stone in Wojcieszów & rocks & 3 & 4 & 4 & 3 & 5 & 3 & 22 \\
\hline 6 & The phyllites quarry in Wojcieszów & $\begin{array}{l}\text { closed } \\
\text { quarry }\end{array}$ & 4 & 4 & 4 & 3 & 4 & 3 & 22 \\
\hline 7 & $\begin{array}{l}\text { The marble quarry at the Miłek Hill in } \\
\text { Wojcieszów }\end{array}$ & $\begin{array}{l}\text { closed } \\
\text { quarry }\end{array}$ & 4 & 4 & 3 & 3 & 5 & 3 & 22 \\
\hline 8 & $\begin{array}{l}\text { Księży Kamień -Priest's Stone near } \\
\text { Radzimowice }\end{array}$ & rocks & 4 & 4 & 3 & 3 & 4 & 2 & 20 \\
\hline 9 & $\begin{array}{l}\text { Adit uranium at the slope of Chmielarz } \\
\text { Hill }\end{array}$ & adit & 4 & 4 & 5 & 3 & 1 & 3 & 20 \\
\hline 10 & Gravel-mine in Okrajnik & $\begin{array}{l}\text { grav- } \\
\text { el-mine }\end{array}$ & 3 & 3 & 5 & 2 & 4 & 3 & 20 \\
\hline 11 & $\begin{array}{l}\text { Lime kiln in Wojcieszów near the Gruszka } \\
\text { quarry }\end{array}$ & lime kiln & 3 & 3 & 4 & 3 & 4 & 2 & 19 \\
\hline 12 & Greenstones at the top of Marciniec Hill & rocks & 3 & 4 & 4 & 2 & 3 & 3 & 19 \\
\hline 13 & "Arnold" shaft in Radzimowice & shaft & 4 & 3 & 5 & 3 & 1 & 2 & 18 \\
\hline 14 & Metatrachytes at the Rogacz Hill & rocks & 3 & 3 & 4 & 2 & 3 & 3 & 18 \\
\hline 15 & The spring Miłek in Wojcieszów & spring & 3 & 2 & 3 & 3 & 5 & 1 & 17 \\
\hline 16 & $\begin{array}{l}\text { Marbles at the slope of Cisowa summit } \\
\text { (Miłek Hill) }\end{array}$ & rocks & 2 & 2 & 5 & 2 & 2 & 3 & 16 \\
\hline 17 & $\begin{array}{l}\text { Natural outcrop of sericite shales in } \\
\text { Wojcieszów Dolny }\end{array}$ & $\begin{array}{l}\text { natural } \\
\text { outcrop }\end{array}$ & 3 & 3 & 4 & 1 & 3 & 2 & 16 \\
\hline 18 & $\begin{array}{l}\text { Marbles at the Młyniec summit (Miłek } \\
\text { Hill) }\end{array}$ & rocks & 2 & 2 & 4 & 2 & 3 & 2 & 15 \\
\hline 19 & The heap in Radzimowice & heap & 2 & 2 & 4 & 2 & 3 & 2 & 15 \\
\hline 20 & Exploration shafts in Radzimowice & shaft & 2 & 2 & 3 & 2 & 4 & 2 & 15 \\
\hline 21 & The Cave Schron Miłek in Wojcieszów & cave & 2 & 2 & 4 & 1 & 3 & 1 & 13 \\
\hline 22 & $\begin{array}{l}\text { Metadiabases at the slope of the Zadora } \\
\text { Hill }\end{array}$ & rocks & 3 & 2 & 3 & 1 & 2 & 1 & 12 \\
\hline
\end{tabular}




\section{Geological setting}

The Wojcieszów area is located in the southern part of the Kaczawa Unit, in the West Sudetes. The unit is composed of two structural complexes: the Variscan basement and epi-Variscan cover (Baranowski et al., 1990). The Bolków - Wojcieszów antiform (Fig. 1) is the main structure of this part of the Kaczawa Unit (Schwarzbach, 1939; Baranowski et al., 1990). Wojcieszów extends over three tectonic units, the Świerzawa unit in the northern part, Radzimowice unit (previously interpreted to be a part of the Bolków unit) and the Bolków unit in its southern part (see Baranowski, 1988; Kryza \& Muszyński, 1992).

The Variscan basement is exposed in Świerzawa and Bolków units and comprises the Kaczawa Complex (sensu Kryza \& Zalasiewicz, 2008), which was metamorphosed and strongly deformed during the Variscan orogeny. The complex is composed of various fragments of the Kaczawa Succession (metavolcanic and metasedimentary rocks) of the Cambrian up to the Viséan age, locally associated with polygenetic mélange bodies of assumed the Late Devonian - Early Carboniferous age (Baranowski et al., 1990; Kryza \& Muszyński, 2003 and references therein; Kryza, 2008).

In the vicinity of Wojcieszów, mainly lower part of the Kaczawa Succession is exposed (Kryza, 2008). It contains metavolcanic-metasedimentary rocks of the Cambrian-Ordovician age (Haydukiewicz, 1987), which are represented by mafic and felsic metavolcanic rocks (basaltic pillow lavas, metarhyodacites and metatrachytes), metavolcaniclastic rocks, crystalline limestones (Wojcieszów limestones) and clastic metasedimentary rocks (mainly metamudstones).

The problem of age of the Wojcieszów limestone was analyzed by many authors for over 125 years (e.g. Gürich, 1929; Schwarzbach, 1936, 1939; Gunia, 1967; Baranowski \& Lorenc, 1978, 1981; Skowronek \& Steffahn, 2000). Recently, the Lower Cambrian archaeocyates were found in this limestone (Białek et al., 2007) and finally settled its age. According to Baranowski \& Lorenc (1981), the Wojcieszów limestones form isolated bodies of various sizes within the greenstones lenses, in some places limestones intimately intercalated with greenstones. The limestones with associated greenstones (at first mafic volcanic rocks) are the oldest elements of the Kaczawa Succession.

The metarhyodacites and metatrachytes were dated using the SHRIMP U-Pb zircon method at. c. 500 and $485 \mathrm{Ma}$, respectively (Kryza et al., 2007). Rocks of the lower part of the Kaczawa Succession are regarded as products of initial rift processes within the Early Paleozoic continental crust setting (Furnes et al., 1994; Kryza \& Zalasiewicz, 2008).

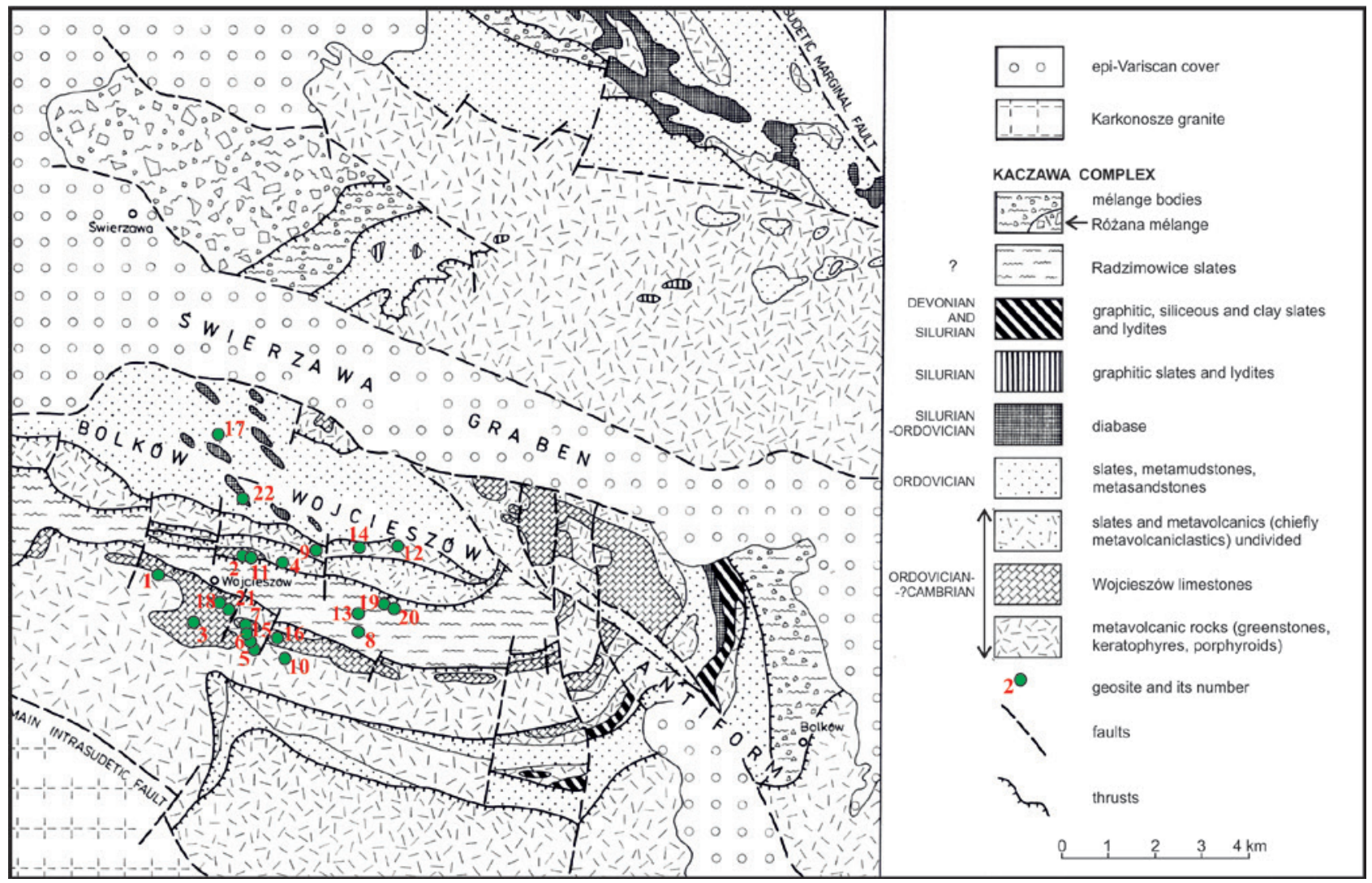

Fig. 1. Simplified geological map of the central part of the Kaczawa Unit based on Baranowski et al. (1990) with proposed attractive geosites (numbers as in Table 1) 
The upper part of the Kaczawa Succession is exposed mainly in the Rzeszówek-Jakuszowa and Dobromierz tectonic units. It is represented by large metabasalt pillow lavas of the MORB-type (mid-ocean-ridge basalts) affinity, associated with condensed, black graptolitic slates and cherts of the Silurian - Devonian age. These rocks had developed in a mature basin, with a rifting regime (see Furnes et al., 1994; Kryza \& Zalasiewicz, 2008).

The Radzimowice unit, probably of the Early Palaeozoic age, comprises assemblages of dark-grey slates with intercalations of siliceous slates, greywackes and quartzites. The Radzimowice Slates have a thickness over $1 \mathrm{~km}$. Their age has been documented by conodonts as no older than the Ordovician, but the upper age limit is still problematic (Urbanek \& Baranowski, 1986). These rocks originally were represented by shaly flysch-type sedimentary rocks and next were metamorphosed at greenschist facies (Baranowski et al., 1990; Kryza \& Muszyński, 2003; Kryza \& Zalasiewicz, 2008). According to Baranowski (1988), the dominance of mudstones over sandstones and the turbidite features of the slates are compatible with sedimentation in a trench-floor or trench-slope basin setting. The new detrital zircon ages obtained by Tyszka et al. (2007) show, that the Radzimowice Slates were deposited as an extensional basin-fill (see Kryza \& Zalasiewicz, 2008). As stated by Baranowski et al. (1990), the margins of the Radzimowice schists are tectonic (faults). This unit separates the Świerzawa unit and the Bolków unit (Kryza \& Muszyński, 1992).

The mélange-type rocks encompass various-sized blocks (clasts and olistoliths) of greywackes, cherts and rare volcaniclastic rocks embedded in a dark, mud-dominated matrix (Kryza, 2008; Kostylew et al., 2017). Rare conodonts and graptolites documented the Ordovician Devonian age of these blocks, while the matrix includes the Devonian - lower Carboniferous material (Haydukiewicz \& Urbanek, 1987). This part of the Kaczawa Succession was developed in an accretionary prism environment during the Variscan Orogeny (Baranowski et al., 1990; Kryza \& Zalasiewicz, 2008).

In general, the metamorphic grade in the Kaczawa Unit varies from very-low grade (Kostylew, 2008) to blueschistoverprinted by greenschist-facies conditions (Kryza et al., 1990; 2011). The late-orogenic Variscan magmatism, which is represented by small subvolcanic intrusions (e.g. the Żeleźniak and Bukowinka intrusions) provide an upper age limit for deeper-level tectonic and metamorphic processes in the Kaczawa accretionary prism (Machowiak et al., 2008). The Variscan deformation also caused WNW- directed thrusting and subsequent ESE-directed normal faulting (Cymerman, 2002; Kryza, 2008 and references therein).

The epi-Variscan cover is separated from the basement by a regional unconformity and formed mainly the North
Sudetic Synclinorium and the Świerzawa Graben. It comprises the upper Pennsylvanian, Permian, Triassic, Upper Cretaceous, Neogene and Quaternary mainly sedimentary rocks, with also the occurrence of volcanic rocks. Variscan structures of the Kaczawa Complex were also modified (rotation and tilting of small blocks) during the Laramian and young Alpine tectonic movements (Teisseyre, 1956; Oberc, 1972).

\section{Characteristic and evaluation of selected geosites}

Rocks which make up the area are very diverse lithologically (sedimentary, volcanic and metamorphic rocks) as well as in age (the early Palaeozoic, late Palaeozoic and Cenozoic). The most attractive geosites in the vicinity of Wojcieszów were selected (Fig. 1, numbers of geosites as in Tab. 1) and proposed to show typical lithologies of the lower part of the Kaczawa Succession (bimodal within-plate metavolcanics and metasedimentary rocks) and pre-Variscan geological evolution of the area. Relics of past mining operations are also described among geological and geomorphological objects. From all analyzed objects, there are twenty two geosites, which are particularly recommendable (Tab. 1).

The most attractive and the largest geosites are numerous quarries of crystalline Wojcieszów limestone (e.g. Silesia, Gruszka, Miłek, Połom; Figs 2-6, Fig. 10). This rock material has been mined since the 16 th century. Wojcieszów limestones (marbles) are represented by different varieties: dark gray, well-layered, light-gray, yellowish, laminated, thin-bedded to striped (Lorenc, 1983). They became sediments in shallow water or deeper marine environments. Limestones and greenstones occur also as blocks (olistoliths) in the epimetamorphic Radzimowice Slates (Baranowski, 1988; Kryza, 2008). Among numerous marble quarries, only the Połom quarry is active. In the marble quarry Silesia, one of the biggest and best preserved, the spectacular isolated blocks (probably olistoliths) of Wojcieszów limestones occur within greenstones (Fig. 3). The marble quarry Gruszka lies on the educational path "Gruszka" and is easily accessible and prepared for tourists (Fig. 4). Currently, in the quarry the "Gruszka Recreation and Leisure Park" and a climbing wall for children and youth are to be found. The Polish Championships in Caves Techniques and the Alpine Festival are organized here. Lime kilns were often situated near marble quarries. A well preserved lime kiln from the 18th century is located near the Gruszka quarry (Fig. 7). Marbles often form hills (e.g. Połom, Miłek), escarpments and towers. The latter are especially visible at the slope of the Cisowa summit (Miłek Hill) (Fig. 8). 

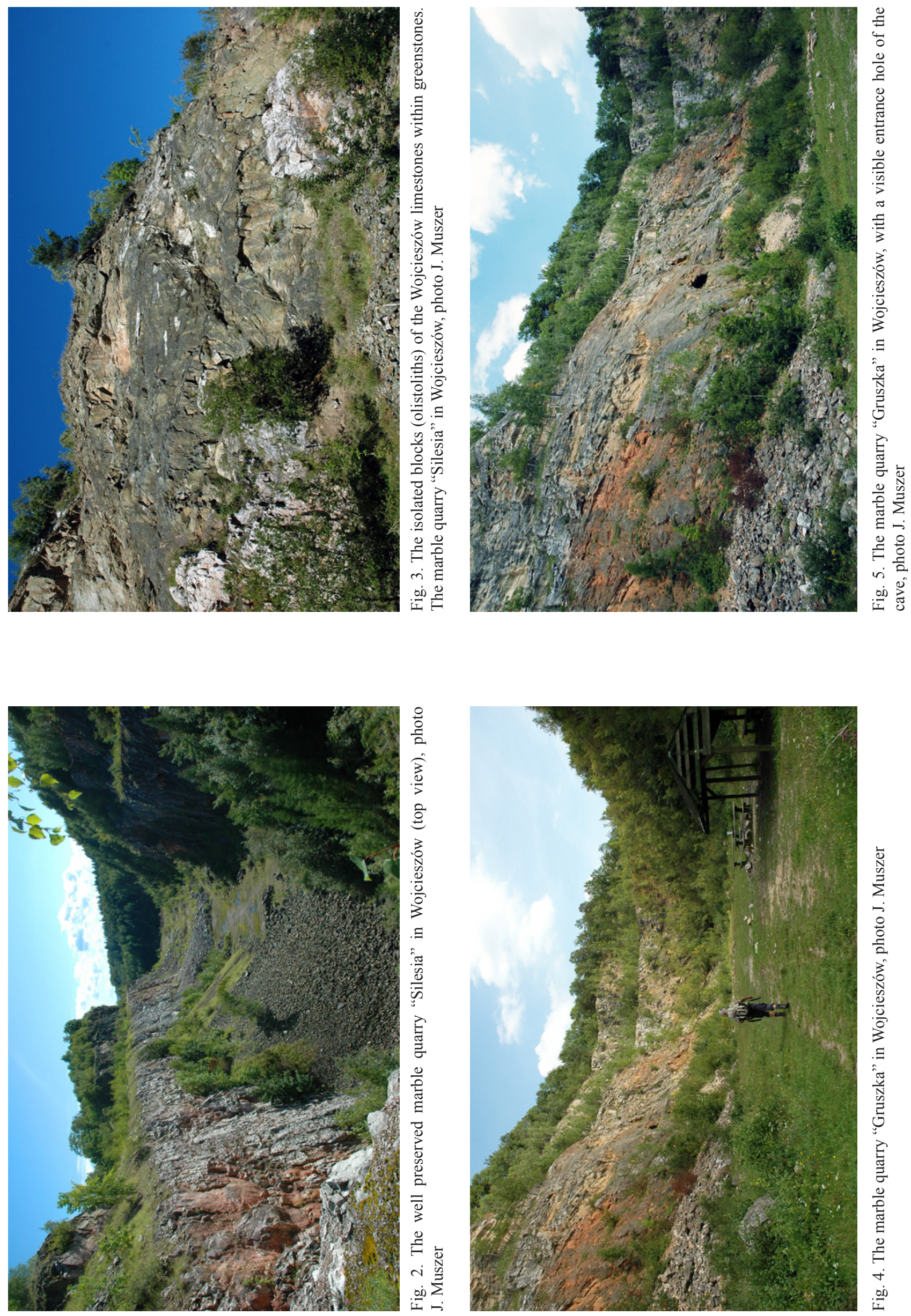


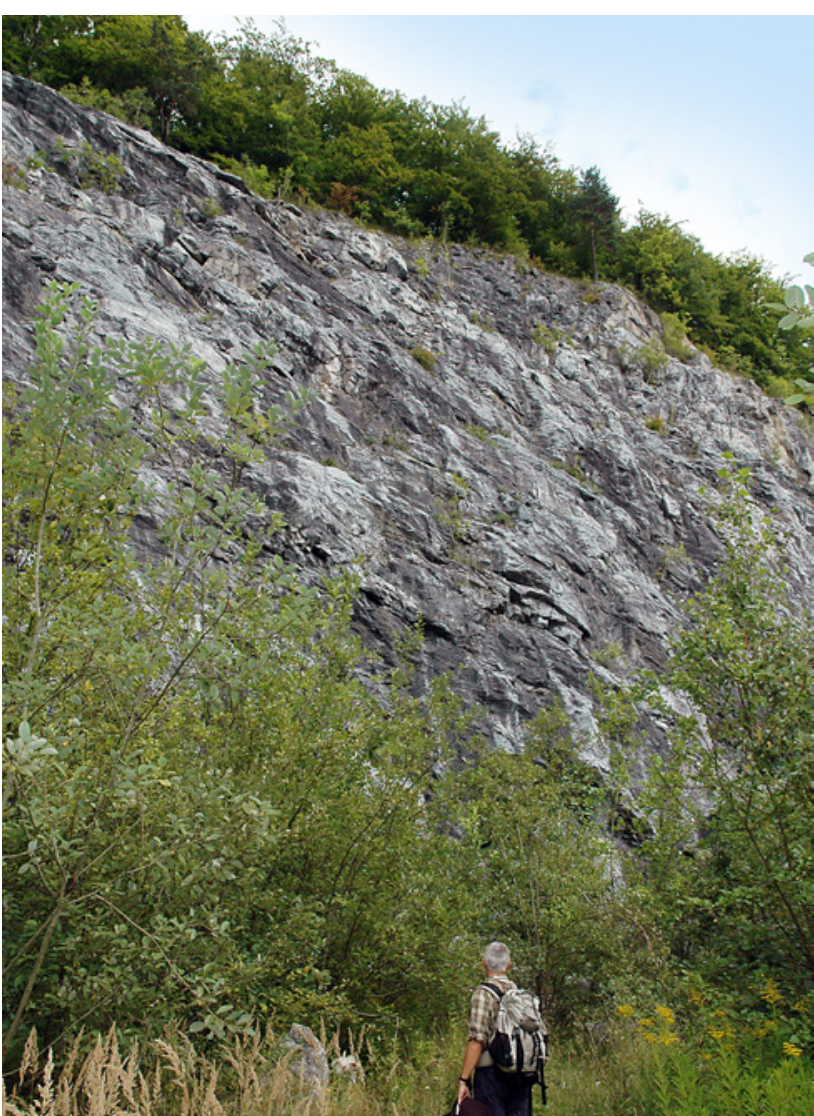

Fig. 6. The marble quarry "Miłek" in Wojcieszów, partly overgrown with vegetation, photo J. Muszer
Wojcieszów limestones are also very interesting for another reason. In this part of the Sudetes, the most intensive karst processes took place in the Paleogene. They have evolved within the limestones at two height levels (see Mianowicz \& Brzozowska, 2009). The upper horizon lies at an altitude of 540-590 meters, and the lower horizon occurs at an altitude 400-430 m. An example of the cave from the upper horizon is the Schron Miłek Cave (Fig. 9), while the cave Aven from the marble quarry Miłek is located at the lower horizon. Archaeological investigations indicate that these caves were used by the Paleolithic man (e.g. Bronowicki, 2001; Mianowicz \& Brzozowska, 2009). Caves are a natural wealth of inanimate nature of the Wojcieszów region, but many of them were destroyed during the exploitation of limestones, especially in the Połom Hill (Fig. 10). Access to existing caves is difficult (example from the quarry Gruszka; Fig. 5), and therefore cannot be used for normal tourist traffic.

The spring Miłek in Wojcieszów (Fig. 11), located at the southern foot of the Miłek Hill on the right bank of the Kaczawa River, is also related to the crystalline Wojcieszów limestones. It is a karst spring, situated near the marble quarry Miłek (Fig. 6), on the "blue" hiking trail. However, geotouristic attractiveness of the spring is not displayed, because the spring is hooded by a well. Water from this spring is bottled and distributed as "Wojcieszowianka" (Marszałek et al., 2008).



Fig. 7. A lime kiln in Wojcieszów situated near the marble "Gruszka" quarry, photo J. Muszer 

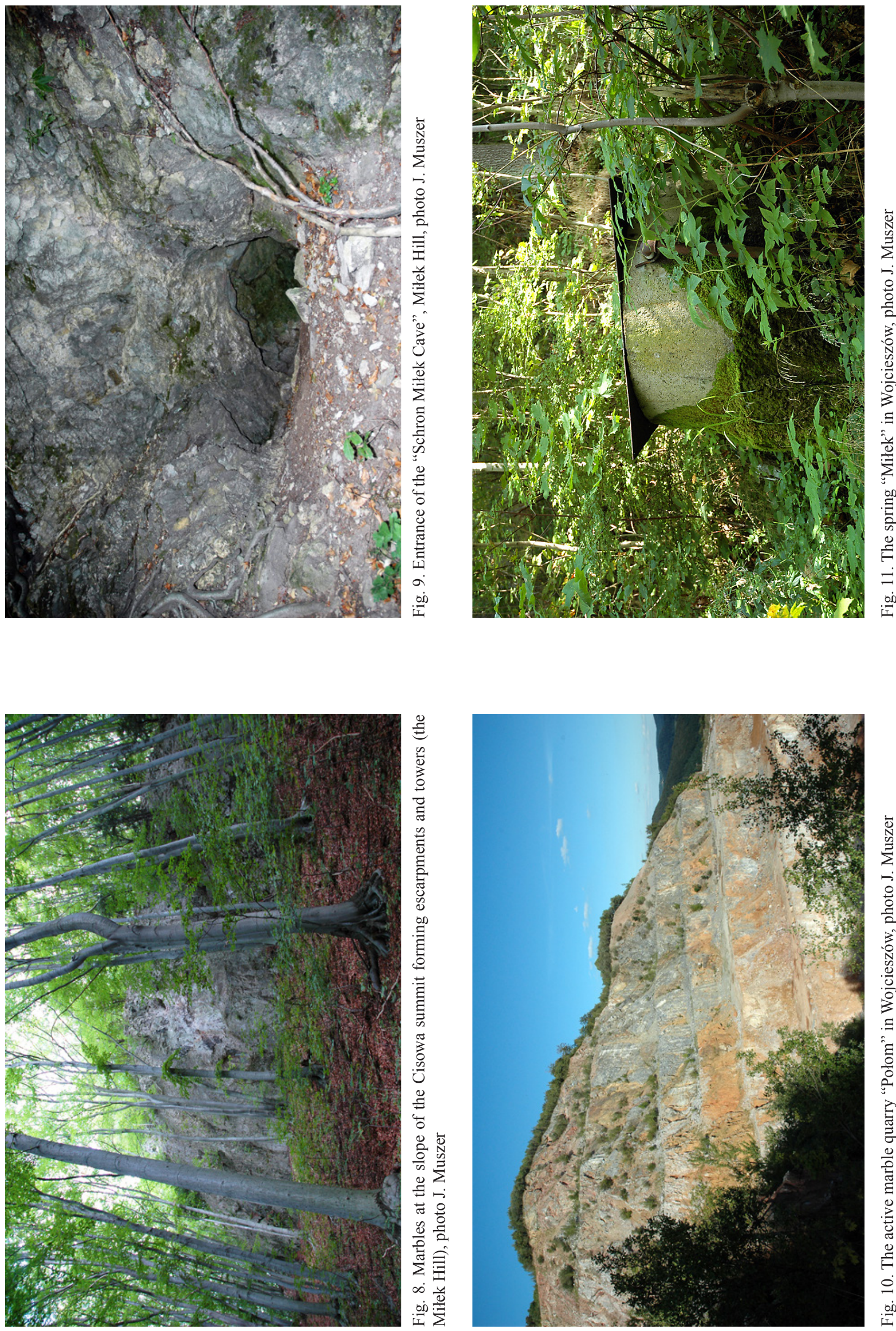

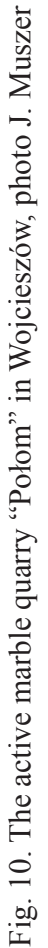


Its temperature is almost stable $\left(12.8-13.4^{\circ} \mathrm{C}\right)$. Chemical analysis shows low alkaline $\mathrm{pH}(7.1-7.6)$, mineralization between $209-409 \mathrm{mg} / \mathrm{L}$ and $\mathrm{HCO}_{3}-\mathrm{Ca}-(\mathrm{Mg})$ type of waters (Bocheńska et al., 2002; Marszałek et al., 2008).

The lower part of the Kaczawa Succession also is represented by metarhyodacites ("porphyroids"), which occur in the southern part of Wojcieszów (Wojcieszów Górny) at the foot of the Miłek Hill and form rocks called "Biały Kamień" - White Stone (Fig. 12). They are strongly sheared, represent a felsic member of the "bimodal volcanic suite" (likely volcaniclastic origin) and dated circa $500 \mathrm{Ma}$ (Kryza, 2008). They were formed during initial continental-rift setting during the Cambrian/Ordovician times. A closed quarry of phyllites is located near these rocks. In this quarry, intensively folded quartzite-sericitic shales occur, with quartzite inserts (Fig. 13). Additionally, these rocks are characterized by goffering.

Another very interesting geosite called "Lisie Skały" - Fox Rocks (Fig. 14) is located at the western slopes of the Chmielarz Hill, about $1.1 \mathrm{~km}$ from the center of Wojcieszów. There are schistosited metarhyodacites intersecting folded sericite-chlorite slates, with greenstones and silica slates inserts. These rocks also contain numerous quartz lenses and veins. The object lies on the natureeducational path "Gruszka".

Natural outcrops of sericite shales (Fig. 15) and metadiabases at the slope of the Zadora Hill (Fig. 16) also occur in the northern part of Wojcieszów (Wojcieszów Dolny). However, these geosites are rather small, less attractive, partly overgrown by vegetation and located away from hiking trails.

Other interesting geosites are located near Wojcieszów, about 3-4 km to the east, in the Radzimowice area. The different types of rocks occur in these geosites. "Księży Kamień" - Priest's Stone (Fig. 17) is located about $1 \mathrm{~km}$ south of Radzimowice. The Radzimowice Unit (the Radzimowice Slates) is exposed in this geosite. The epimetamorphic slates are green-gray with lenses of graphite and siliceous slates. Attractive outcrops of greenstones occur at the top of the Marciniec Hill (Fig. 18) and magnificent rocks of metatrachytes protrude at the Rogacz Hill (Fig. 19).

At the southern and eastern slopes of the Żeleźniak Hill near Radzimowice, there are a lot of traces of the former mining of polymetallic ores (Manecki \& Młodożeniec, 1959, 1960; Manecki, 1962, 1963, 1965; Dziekoński,
1972; Holeczek \& Janeczek, 1991; Siuda, 2001, 2002, 2003, 2004; Mikulski, 2005, 2007; Madziarz, 2009). The polymetallic Au-As-Cu deposit of Radzimowice, formerly known as "Stara Góra", occurs in the Radzimowice Unit. In the early Pennsylvanian (the late Carboniferous, late Namurian, c. $315 \mathrm{Ma}$ ) the schists were crosscut by volcanic dykes and subvolcanic Żeleźniak intrusion (see Machowiak, 2002; Machowiak et al., 2008 and references herein), which has the shape of a laccolith (see Mikulski, 2007). The upper part of the intrusion is built up of rhyolites, rhyodacites, dacites and trachyandesites, whereas its deeper part is represented by granitoids (see Machowiak \& Niemczyk, 2005). The Radzimowice Slates and the intrusion are crosscut by lamprophyres (kersantites) (Manecki, 1965).

The deposit of Radzimowice was exploited intermittently since the end of 12 th century up until year 1925 (Mikulski, 2007). This ore-deposit is genetically connected with hydrothermal activity of the Żeleźniak intrusion and consists of some ore veins crosscutting Radzimowice Slates and volcanic rocks. The most common minerals of veins are arsenopyrite, chalcopyrite, pyrite, marcasite, galena and sphalerite, while bournonite, boulangerite, tetrahedrite, bismuth, gold, löllingite, stibnite and cobaltite have also been reported (Manecki, 1965; Zimnoch, 1965; Mikulski, 2005). The main subject of exploitation was the gold-bearing arsenopyrite and chalcopyrite. The remains of the mining activity are an extensive system of adits and shafts. The "Arnold" shaft (Fig. 20) and small exploration shafts in Radzimowice (Fig. 21) are good examples of this activity. The heap in Radzimowice (Fig. 22) is located near "blue" hiking trail and the "Luis" shaft. However the heap is partly overgrown by vegetation and access to it is difficult.

Probably uranium anomalies are associated with the same intrusion in the region of the Chmielarz Hill. The adit uranium at the slope of this hill (Fig. 23) is a remnant of the prospection for this element after the Second World War. It is currently inaccessible for sightseeing and is protected by the chiropterological company "ProNatura".

The last proposed geosite is the active gravel-mine in Okrajnik (Fig. 24) located on the pass between the Wroniec Hill and the Osełka Hill. This object is large, with well exposed gravels and sandstones of fluvioglacial origin and the Quaternary (Pleistocene) age. Another smaller gravel-mine is located in Stara Kraśnica. 

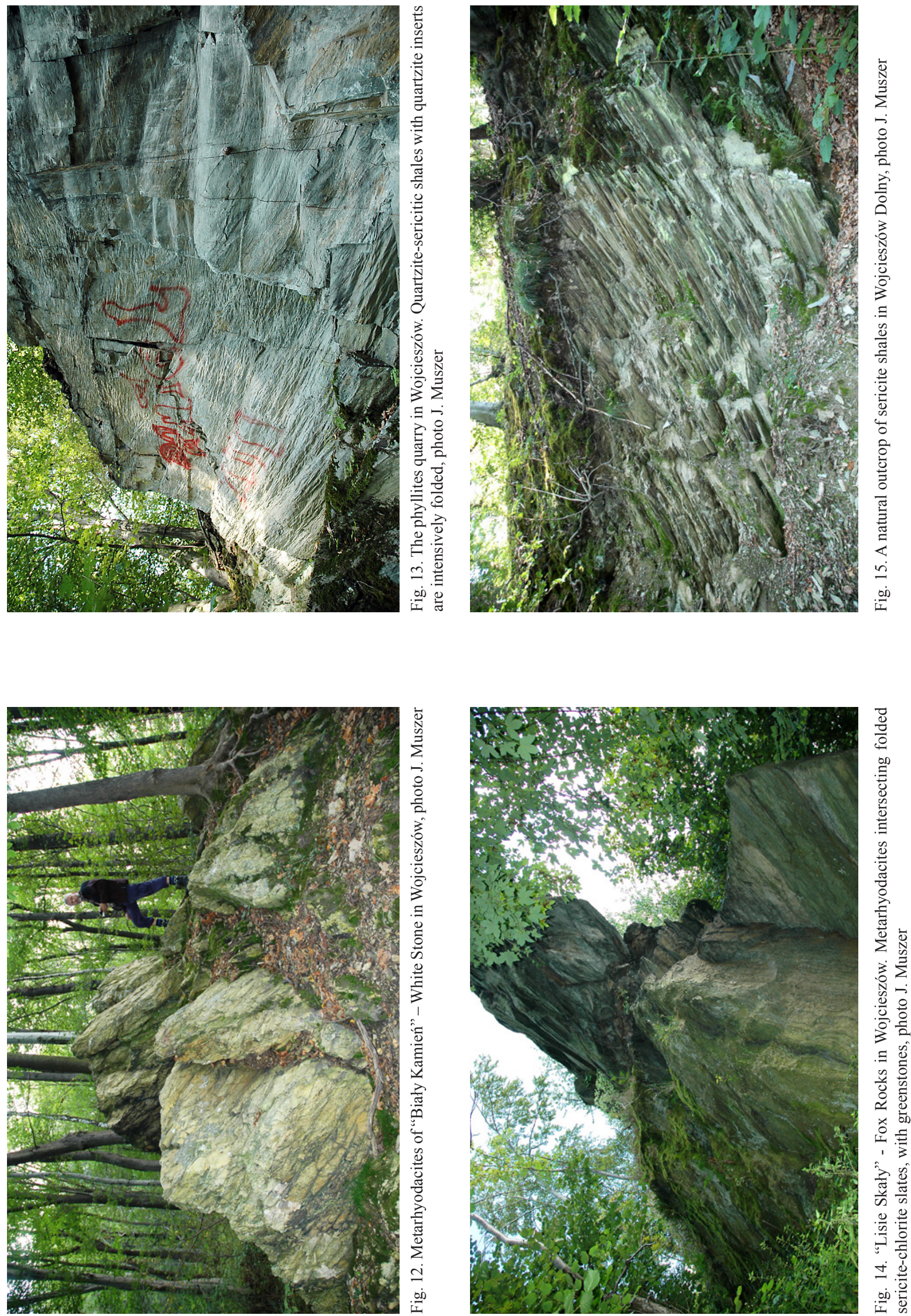

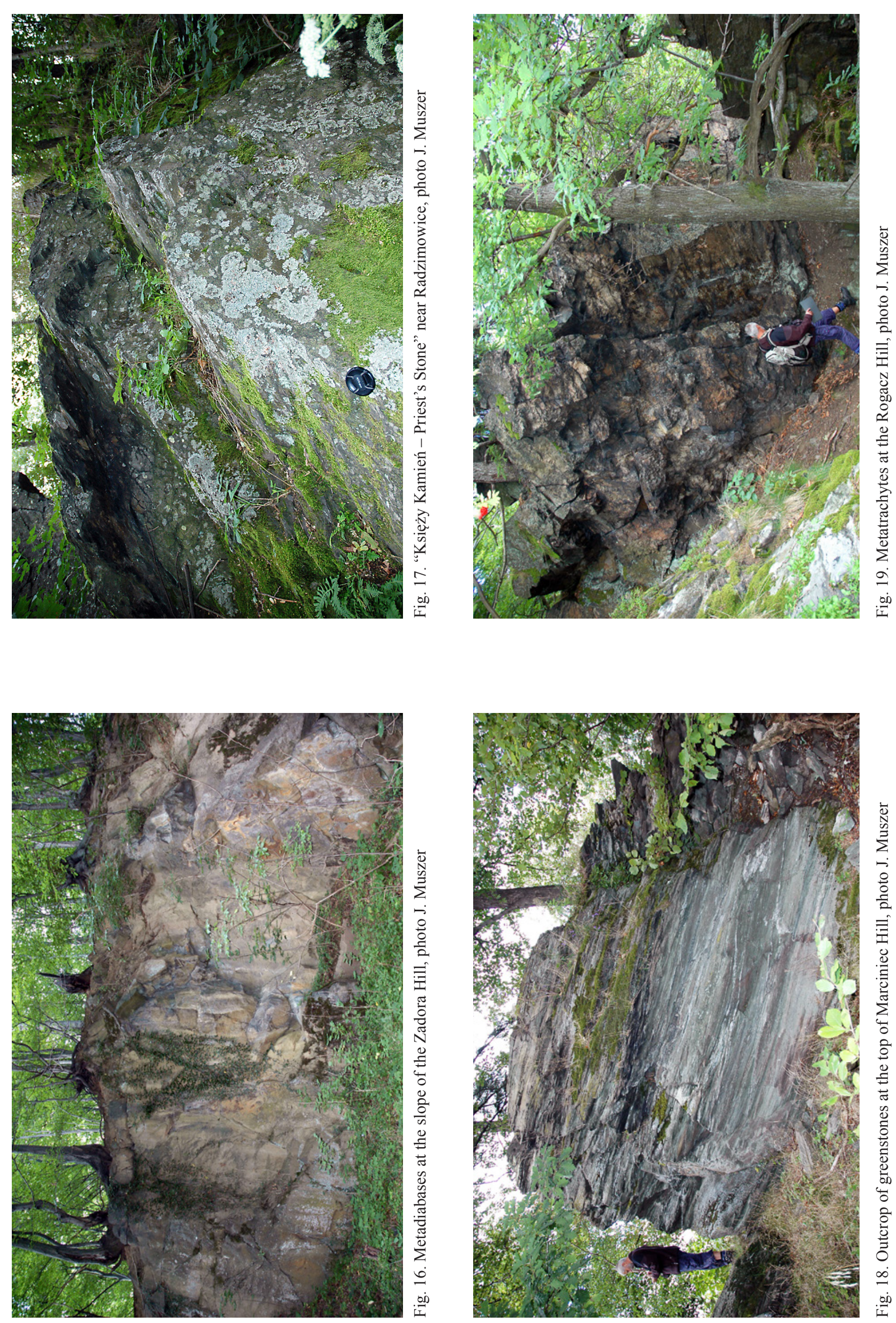

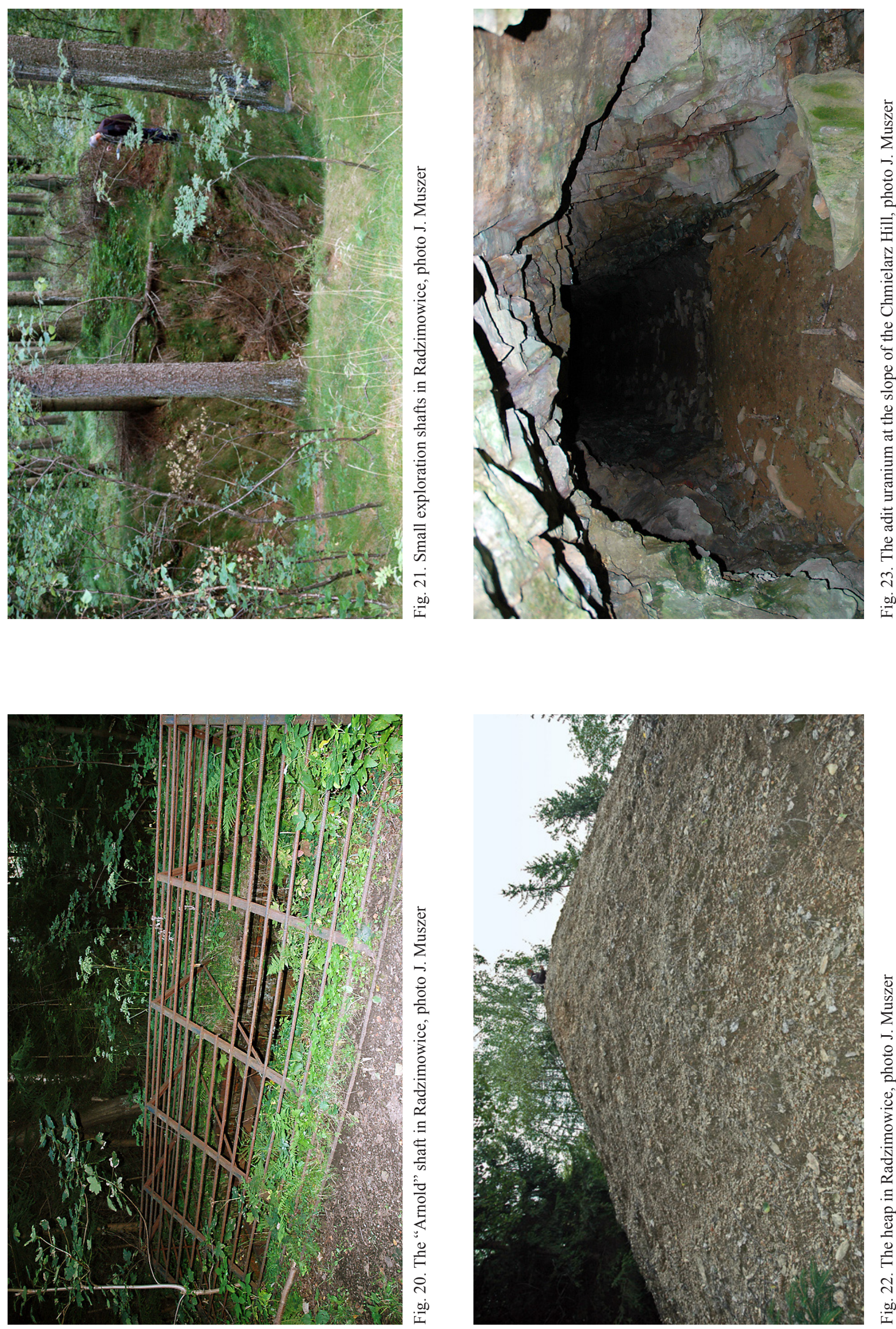


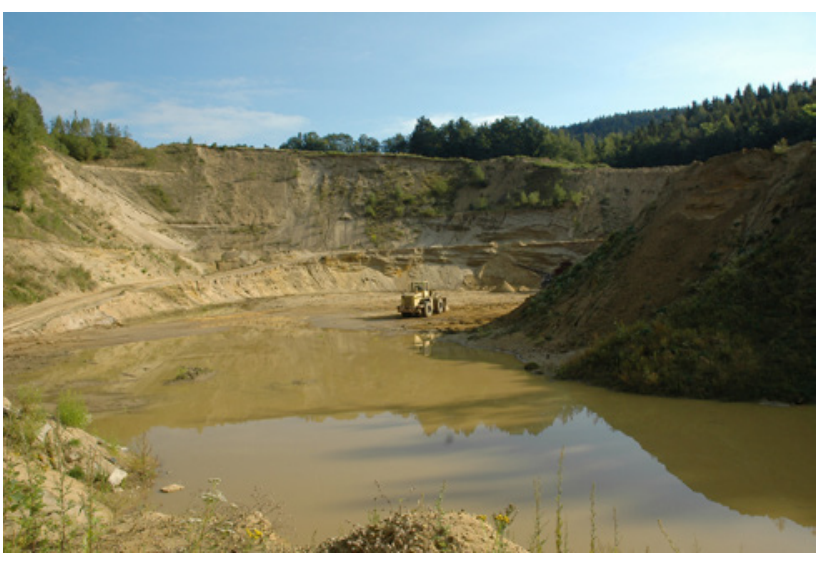

Fig. 24. The active gravel-mine in Okrajnik, photo J. Muszer

\section{Nature protection}

\section{and quarry management}

Currently, the Miłek Hill (596 m a.s.1.) is the only legally protected reserve in the Wojcieszów area. Rocks on the summits of the hill were considered as natural monuments even before the Second World War. A nature reserve "Góra Miłek" of 141.36 hectares was created in 1994. It protects the forest communities of fertile beech forest and warm-weather orchid beech forest, as well as thermophilic plant associations on outcrops of limestone rocks (Mianowicz \& Brzozowska, 2009). There are 24 protected floral species (e.g. Cypripedium, Platanthera bifolia, Cephalanthera longifolia, Cyclamen purpurascens) in the reserve and some unique species of invertebrates (e.g. gastropod Pyramidula rupestris and spider Prospotheca corniculas) (see Mianowicz \& Brzozowska, 2009). There are also numerous species of bats.

The Połom Hill (667 $\mathrm{m}$ a.s.1.), which is located on the left bank of the Kaczawa River, opposite to Miłek Hill, is also built of the Cambrian crystalline limestones, which are locally dolomitized with many calcite veins. This hill was formerly a nature reserve, which was liquidated in the late 1970s. Exploitation of marble has continued for hundreds of years, leading to the characteristic "biting" outline of the hill. Quarries on the Połom Hill are very extensive, multi-level, with walls of exploitation level exceeding $20 \mathrm{~m}$ in height (Fig. 10). The most famous caves in the Wojcieszów region are located on the Połom Hill (33 documented caves), but a dozen of them (13 caves) were destroyed or buried as a result of progressing work (e.g. Pulina 1996; Zyzańska \& Szynkiewicz 2003). Unfortunately their total number is unknown, due to the limited access of scientists and speleologists to the quarries. Some of the described caves no longer exist: Porcelanowa, Naciekowa, Meandrująca, Jasna and Gwiaździsta (see Mianowicz \& Brzozowska 2009). The efforts of environmentalists and speleologists have so far failed to produce any results, and there is no plan to establish legally protected areas in the quarry.

Problems of quarry management after end of limestone exploitation on the Połom Hill were presented by Zyzańska \& Szynkiewicz (2003). These authors ascertained that the main method of "post-mining reclamation" were infilling of quarries with wastes (mining, industrial and municipal). Cited authors suggested several alternation solutions e.g. protection part of rocks escarpment as a geological document point or as nature monuments (especially caves) or as teaching geological path. Some fragments of quarries could also be used for optional caving, climbing, diving, fishing and recreation.

Another example of improper use of quarries was the localization of a dump site in the area. In the 20th century, in the Wojcieszów area, there was a dump site in one of the marble quarries, which is situated only about $1.5 \mathrm{~km}$ from the center of the town. Rubbish fills the lower part of the quarry and makes a very depressing impression (Fig. 25). On 31 May of 2009, this dump site was closed, because it threatened the pollution of groundwater.

Wojcieszów, which is picturesquely situated in the valle River, is heavily neglected and has a poorly developed tourist infrastructure. Contemporary, local authorities, among other activities, aim to develop tourism in the region through the implementation of many ecotourism and geotourism projects in accordance with the principles of sustainable development. It is planned to create trails showing the traces of the old mining in the Radzimowice area.

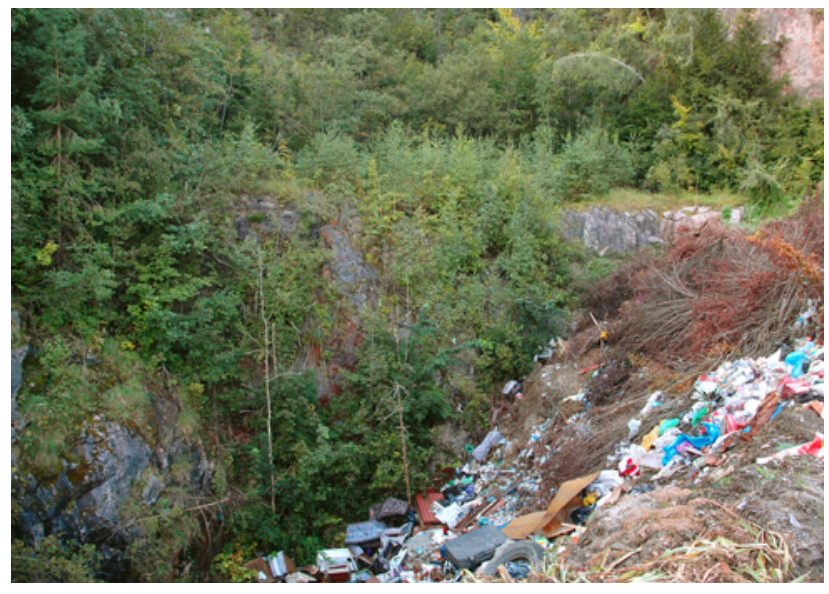

Fig. 25. Dump site in the marble quarry in Wojcieszów closed since 2009, photo J. Muszer 
Since 2008, the Wojcieszów area was included in the Special Area of Conservation The Kaczawskie Mts. and Kaczawa Foothill (Góry and Pogórze Kaczawskie) (PLH020037) of Natura 2000, which is a network of protected sites across the European Union. This area of conservation is very important in the Lower Silesia and protects twenty five types of habitats (Świerkosz et al., 2012). It can help in the development of ecotourism and geotourism in this area.

\section{Conclusions}

Łodziński et al. (2009) presented only one geosite (the marble quarry Miłek) as the most important in this region. Our evaluation of geosites in the studied area shows that there are much more interesting sites in Wojcieszów (see Table 1, large marble quarries: Silesia, Gruszka, Połom; natural exposures of metaryodacites Lisie Skały and Biały Kamien; the phyllites quarry). The main geotouristic values of the Wojcieszów area are: enormous diversity of geological structure, lithology and relief in a relatively small area, numerous exposures and quarries and spectacular human impact. The natural resources of this area since the 16 th century have contributed to the development of this town. Rock raw materials (crystalline limestone, phyllites, metaryodacides, etc.) and also metallic minerals (copper, iron, gold, etc.) have been mined there. In addition, natural springs of water have been exploited. The most attractive geosites surrounding Wojcieszów demonstrate typical lithologies of the Kaczawa Succession, which shows the geological pre-Variscan evolution of the area.

As a result of human activity in the vicinity of Wojcieszów, the environment has changed significantly. Many caves, habitats and even landscapes have been destroyed (e.g. slope damage, heaps, numerous excavations, adits, shafts). Economic considerations also have determined the liquidation of the Połom Hill reserve. In the analyzed area, both resources and values at the same time, so the conflict between economic development and nature protection overlaps.

However, economic activity, which destroyed some protected objects has also paradoxically contributed positively to the geodiversity of this area (with exception of the Połom Hill). Potential tourists can explore the rocks of this region, geological and mining history, find interesting minerals and fossils, practice speleology and enjoy mountain tourism. The proposed geosites can be used both in the sustainable development of the town and in the municipality, as well as in shaping the positive image of the sub-region for tourism, especially geotourism.

\section{Acknowledgements}

Execution of this work was possible due to the financial support provided by the Ministry of Environment, through the National Fund for Environment Protection and Water Management (No 490/2008/Wn-06/FG-bp-tx/D) and the grant ING UWr 0401/0157/17. We thank anonymous reviewers for their helpful remarks.

\section{References (Literatura)}

Baranowski Z., 1988. Lithofacies characteristic of trench-fill metasediments in the Radzimowice Slate (Paleozoic), Sudetes, SW Poland. Annales Societatis Geologorum Poloniae, 58: 325-383.

Baranowski Z. \& Lorenc S., 1978. Trilobite remnants in the Wojcieszów crystalline limestone (Góry Kaczawskie, Sudetes Mts.). Bulletin L'Academie Polonaise des Sciences, Série des Sciences de la Terre, 25: 99-102.

Baranowski Z. \& Lorenc S., 1981. Pozycja geologiczna wapieni wojcieszowskich względem serii zieleńcowej (spilitowo-keratofirowej) w SE części Gór Kaczawskich. Geologia Sudetica, 16: 49-59.

Baranowski Z., Haydukiewicz A., Kryza R., Lorenc S., Muszyński A., Solecki A. \& Urbanek Z., 1990. Outline of the geology of the Góry Kaczawskie (Sudetes, Poland). Neues Jahrbuch für Geologie und Paläontologie. Abhandlungen, 179: 223-257.

Bartuś T., 2015. Geotourist maps of the Sudetic Geostrada Trail as a new form of popularization of geotourism in the Sudety Mts. Geoturystyka. Geotourism, 1-2 (40-41): 3-18.

Bartuś T., Mastej W. \& Łodziński M., 2009. Atrakcje geoturystyczne Geostrady Środkowosudeckiej. Geotourist attractions of the Central Sudetic Geostrada. Geoturystyka. Geotourism, 4(19): 43-60.

Białek D., Raczyński P., Sztajner P. \& Zawadzki D., 2007. Archeocjaty wapieni wojcieszowskich. Przeglad Geologiczny, 55, 12: 1112-1116.

Bocheńska T., Marszałek H. \& Wąsik M., 2002. Zbiorniki wód podziemnych w obszarach krasowych krystaliniku sudeckiego. Acta Universitatis Wratislaviensis, 2460, Wydawnictwo Uniwersytetu Wrocławskiego. Wrocław.

Bronowicki J., 2001. Uwagi na temat osadnictwa z epoki kamienia w okolicach Wojcieszowa w Górach Kaczawskich. Silesia Antiqua, 42: 43-47.

Cwojdziński S, Kozdrój W., 1994. Szczegółowa Mapa Geologiczna Sudetów 1 : 25 000. Arkusz Wojcieszów. Państwowy Instytut Geologiczny. Warszawa.

Cymerman Z., 2002. Analiza strukturalno-kinematyczna i waryscyjska ewolucja tektoniczna kompleksu kaczawskiego. Prace Państwowego Instytutu Geologicznego, 175: 1-147.

Dziekoński T., 1972. Wydobywanie i metalurgia kruszców na Dolnym Śląsku od XIII do połowy XX wieku. Zakład Narodowy im. Ossolińskich. Wydawnictwo PAN, Wrocław.

Furnes H., Kryza R., Muszyński A., Pin C. \& Garmann L.B., 1994. Geochemical evidence for progressive rift-related volcanism in the eastern Variscides. Journal of the Geological Society of London, 15: 91-109. 
Gunia T., 1967. Cambrotrypa (Tabulata) z metamorfiku Sudetów Zachodnich. Rocznik Polskiego Towarzystwa Geologicznego, 37: 417-428.

Gürich G., 1929. Silesicaris von Leipe und die Phyllocariden überhaupt. Mitteilungen aus dem mineralogisch-geologischen Staatsinstitut in Hamburg, 11: 21-90.

Haydukiewicz A. 1987. Sekwencja stratygraficzna w kompleksie kaczawskim. In: Przewodnik 59. Zjazdu PTG w Watbrzychu, Wałbrzych, 17-19 września 1987: 95-102.

Haydukiewicz A. \& Urbanek Z. 1987. Melanż z Rzeszówka (dolina potoku Kamiennik). In: Przewodnik 58. Zjazdu Polskiego Towarzystwa Geologicznego, Wałbrzych, 17-19 września 1987: 112-114.

Holeczek J. \& Janeczek J., 1991. Pseudomalachite from Radzimowice and some comments on its occurrence in Miedzianka (Sudetes Mts.). Mineralogia Polonica, 22(1): 17-26.

Kassenberg A. \& Marek M.J., 1986. Ekologiczne aspekty przestrzennego zagospodarowania kraju. PWN, Warszawa.

Kistowski M., 1996. Analiza występowania potencjalnych sytuacji konfliktowych w środowisku przyrodniczym wspomagana systemem GIG MapInfo (na przykładzie Kaszubskiego Parku Krajobrazowego). In: Kistowski M. (ed.), Badania ekologiczno-krajobrazowe na obszarach chronionych, Problemy Ekologii Krajobrazu, 2. Gdańsk: 8-12.

Kostylew J. 2008. Very low-grade metamorphism in the Variscan accretionary prism of the Kaczawa Complex (Sudetes, SW Poland): new data from illite 'crystallinity' index. Mineralogical Society of Poland-Special Papers, 32: 98.

Kostylew J., Zalasiewicz J.A. \& Kryza R., 2017. Pervasive near-surface stratal disruption in an accretionary prism setting: Kaczawa Complex, SW Poland. Geological Magazine, 154: 651-660.

Kryza R. 2008. The Variscan Kaczawa Complex: witness of Palaeozoic basins and Variscan orogeny. In: Solecki A.T. (ed.), Geoeducational potential of the Sudety Mts. University of Wrocław, Institute of Geological Sciences, Wrocław: 17-26.

Kryza R. \& Muszyński A., 1992. Pre-Variscan volcanic-sedimentary succession of the central southern Góry Kaczawskie, SW Poland; outline geology. Annales Societatis Geologorum Poloniae, 62: 117-140.

Kryza R. \& Muszyński A., 2003. Kompleks metamorficzny Gór Kaczawskich - fragment waryscyjskiej pryzmy akrecyjnej. In: Ciężkowski W., Wojewoda J., Żelaźniewicz A. (eds), Sudety Zachodnie: od wendu do czwartorzędu. Wind, Wrocław: 95-104.

Kryza R. \& Zalasiewicz J., 2008. Records of Precambrian - Early Palaeozoic volcanic and sedimentary processes in the Central European Variscides: a review of SHRIMP zircon data from the Kaczawa succession (Sudetes, SW Poland). Tectonophysics, 461: 60-71.

Kryza R., Mazur S., Aleksandrowski P., Zalasiewicz J., Sergeev S. \& Presnyakov S., 2007. Ordovician initial-rift volcanism in the Central European Variscides (the Kaczawa Mountains, Sudetes, SW Poland): evidence from SHRIMP dating zircons. Journal of the Geological Society, London, 164: 1207-1215.

Kryza R., Muszyński A. \& Vielzeuf D., 1990. Glaucophane-bearing assemblage overprinted by greenschist-facies metamorphism in the Variscan Kaczawa complex, Sudetes, Poland. Journal of Metamorphic Geology, 8: 345-355.

Kryza R., Willner A., Massonn H.-J., Muszyński A. \& Schertl H.-P., 2011. Blueschist-facies metamorphism in the Kaczawa Mountains (Sudetes, SW Poland) of the Central-European Variscides:
P-T constraints by a jadeite-bearing metatrachyte. Mineralogical Magazine, 75: 241-263.

Lorenc S., 1983. Petrogeneza wapieni wojcieszowskich. Geologia Sudetica, 18, 1: 61-119.

Łodziński M., Mayer W., Stefaniuk M., Bartuś T. \& Mastej W., 2009. Atrakcje geoturystyczne Geostrady Zachodniosudeckiej. Geoturystyka, 4(19): 19-42.

Machowiak K., 2002. Petrologia i wiek skał magmowych rejonu Żeleźniaka w Górach Kaczawskich. Archiwum Instytutu Geologii UAM w Poznaniu.

Machowiak K. \& Niemczyk W., 2005. Skały subwulkaniczne Żeleźniaka w Górach Kaczawskich na tle granitu Karkonoszy. Przegląd Geologiczny, 54, 1: 51-55.

Machowiak K., Armstrong R., Kryza R. \& Muszyński A., 2008. Late-orogenic magmatism in the Central European Variscides: SHRIMP U-Pb zircon age constraints from the Żeleźniak intrusion, Kaczawa Mountains, West Sudetes. Geologia Sudetica, 40: $1-18$.

Madziarz M., 2009. Kopalnie "Czarnów”, "Miedzianka” i "Stara Góra” w poszukiwaniach okruszcowania uranowego oraz rud metali w latach 40. i 50. XX w. In: Zagożdżon P.P. \& Madziarz M. (eds.), Dzieje górnictwa - element europejskiego dziedzictwa kultury, 2: 166-193.

Manecki A., 1962. Mineralizacja miedzią występująca w rejonie Bukowej Góry koło Radzimowic (Dolny Śląsk). Sprawozdanie $z$ Posiedzeń Komisji Naukowej PAN Oddziat w Krakowie, 5(2): 460-461.

Manecki A., 1963. Intruzje lamprofirowe w okolicy Radzimowic na Dolnym Śląsku. Sprawozdanie z Posiedzeń Komisji Naukowej PAN Oddzial w Krakowie, 7(2): 538-539.

Manecki A., 1965. Studium mineralogiczno-petrograficzne polimetalicznych żył okolic Wojcieszowa (Dolny Śląsk). Prace Mineralogiczne, 2: 1-71.

Manecki A. \& Młodożeniec W., 1959. Kobaltonośne żyły złoża "Stara Góra” na Dolnym Śląsku. Przegląd Geologiczny, 7(10): 466-467.

Manecki A. \& Młodożeniec W., 1960. Wyniki dotychczasowych badań polimetalicznego złoża Stara Góra. Rudy i Metale Nieżelazne, 9: $380-383$.

Marszałek H., Rysiukiewicz M. \& Wąsik M., 2008. Geotouristic significance of selected springs in the Sudetes. In: Solecki A. (ed.), Geoeducational potential of the Sudety Mts. Fundacja Ostoja, Wrocław: 113-123.

Mianowicz K. \& Brzozowska K., 2009. Potencjał geoturystyczny Wojcieszowa (Góry Kaczawskie). In: Dutkowski M. (ed.) Problemy turystyki i rekreacji, 2. Uniwersytet Szczeciński, Wydział Nauk Przyrodniczych, Instytut Nauk o Ziemi, Wydawnictwo Oficyna IN PLUS, Szczecin: 19-23.

Migoń P., 2014. Góry i Pogórze Kaczawskie. W Krainie Wygastych Wulkanów. Ilustrowany przewodnik z mapami. Wydawnictwo Turystyczne "Plan", Jelenia Góra.

Migoń P. \& Pijet-Migoń E., 2010. Problemy udostępniania turystycznego obiektów wulkanicznego dziedzictwa Ziemi na przykładzie Pogórza Kaczawskiego. Zeszyty Naukowe Wyższej Szkoty Bankowej, 17: 129-151.

Mikulski S.Z., 2005. Geological, mineralogical and geochemical characteristics of the Radzimowice Au-As-Cu deposit from the Kaczawa Mountains (Western Sudetes, Poland) - an example of the transition of porphyry and epithermal style. Mineralium Deposita, 39, 8: 904-920. 
Mikulski S.Z., 2007. The late Variscan gold mineralization in the Kaczawa Mountains, Western Sudetes. Polish Geological Institute Special Papers, 22: 1-162.

Oberc J. 1972. Sudety i obszary przyległe. In: Budowa geologiczna Polski, T. 4, Tektonika, cz. 2. Wydawnictwo Geologiczne, Warszawa.

Otok S., 1990. Natural environment in social policy of the state. In: Otok S. (ed.), Environment in Social Policy of the State, Warsaw: Warsaw University: 23-30.

Pijet-Migoń E. \& Migoń P., 2009. Projekt "W krainie wygasłych wulkanów” szansą dla rozwoju turystyki zrównoważonej na Pogórzu Kaczawskim, In: Marak J., Wyrzykowski J. (eds), Rola turystyki $w$ gospodarce regionu, vol. II. Ustugi turystyczne jako podstawa gospodarki turystycznej, Wyższa Szkoła Handlowa we Wrocławiu, Wrocław, 338-345.

Pulina M., 1996. Jaskinie Sudetów. Polskie Towarzystwo Nauk o Ziemi, Warszawa: 1-202.

Redclift M., 1992. Sustainable development and global environmental change. Global Environmental Change, 2: 32-42.

Rogowski M., 2016. The potential of the Sudetes Mountains for the development of geotouristic products. Geotourism, 3-4 (46-47): 59-80.

Różycka M., 2014. Atrakcyjność geoturystyczna okolic Wojcieszowa w Górach Kaczawskich. Przegląd Geologiczny, 62, 10: 514-520.

Schwarzbach M., 1936. Oberlausitzer Schiefergebirge und Boberkatzbachgebirge - ein stratigraphisch-tektonisch Vergleich. Abhandlungen der Naturforschenden Gesellschaft zu Görlitz, 32, 3: 31-69.

Schwarzbach M., 1939. Die Tektonik des Bober-Katzbach-Gebirges. Alte und junge Gebirgsbildung in einem Teilgebiet der Sudeten. Jahresbericht der Schlesischen Gesellschaft für Vaterländischen Kultur, Naturwissenschaftlich-medizinische Reihe, 113: 1-52.

Sharples C., 2002. Concepts and Principles of Geoconservation. Tasmanian Parks \& Wildlife Service website, [online], Available from: http://www.dpiw.tas.gov.au/inter,nsf/Attachments/SJON-57W3YM/ \$FILE/geoconservation.pdf [accessed: 9.06.2017].

Siuda R., 2001. New sulphate minerals from the Stara Góra oxidised zone, Radzimowice, Kaczawskie Mts. Mineralogical Society of Poland-Special Papers, 18: 186-188.
Siuda R., 2002. Titanium mineralization of the Stara Góra deposit (Kaczawskie Mountains, Poland) and its crystallization conditions. Mineralogical Society of Poland - Special Papers, 20: 195-197.

Siuda R., 2003. Nonconsolidated, hypergenic oxyhydroxides of iron from Stara Góra - mineralogy and geochemistry. Mineralogical Society of Poland - Special Papers, 22: 197-199.

Siuda R., 2004. Iron arsenates from the Stara Góra deposit at Radzimowice in Kaczawskie Mountains, Poland - a preliminary report. Mineralogical Society of Poland - Special Papers, 24: 345-348.

Skowronek A. \& Steffahn J., 2000. The age of the Kauffung Limestone (W Sudetes, Poland) - a revision due to new discovery of microfossils. Neues Jahrbuch für Mineralogie. Monatshefte, 2: 65-82.

Słomka T., Bartuś T., Mastej W., Łodziński M., Mayer W., Stefaniuk M., Doktor M., Koźma J. \& Cwojdziński S., 2009. Koncepcja projektu: "Geostrada Sudecka - studium geologiczno-krajobrazowe z inwentaryzacją obiektów dziedzictwa przyrody nieożywionej". Geoturystyka, 4(19): 3-18.

Świerkosz K., Liberacka H., Łysiak M. \& Zając K. (eds), 2012. Obszary Natura 2000 na Dolnym Ślasku. Regionalna Dyrekcja Ochrony Środowiska we Wrocławiu, Wrocław.

Teisseyre H., 1956. Depresja Świebodzic jako jednostka geologiczna. Biuletyn Instytutu Geologicznego, 106: 5-60.

Tyszka R., Kryza R., Zalasiewicz J.A. \& Larionov A.N., 2007. Multiple Archean to Early Palaeozoic events in the northern Godwana margin witnessed by detrital zircons from the Radzimowice Slates, Kaczawa Complex (Central European Variscides). Geological Magazine, 145, 1: 85-93.

Urbanek Z. \& Baranowski Z., 1986. Revision of age of the Radzimowice schists from the Góry Kaczawskie, Western Sudetes. Annales Societatis Geologorum Poloniae, 56, 3/4: 399-408.

Zimnoch E., 1965. Okruszcowanie złoża Starej Góry w świetle nowych danych. Biuletyn Geologiczny, 5, Wydział Geologii UW, Warszawa.

Zyzańska H. \& Szynkiewicz A., 2003. Problemy zagospodarowania poeksploatacyjnych wyrobisk w wapieniach na Górze Połom w Wojcieszowie (Góry Kaczawskie, Sudety). In: Ksztaltowanie krajobrazu terenów poeksploatacyjnych $w$ górnictwie. Międzynarodowa Konferencja Naukowa, Kraków 10, 11, 12 grudnia $2003 r:$ :304-316.

This paper is extended versions of presentations delivered during the III Forum GEO-PRODUKT: "From geoeducation to innovation", which was held on September, 22-24, 2017 in Wojsławice, Poland (Sudetic Foreland Geopark). For details, please, visit the webpage http://geoprodukt2017.geopark.org.pl.

Niniejszy artykuł stanowi rozszerzenie referatu wygłoszonego w ramach III Forum GEO-PRODUKT: "Od geoedukacji do innowacji”, które odbyło się w dniach 22-24 września 2017 roku w Wojsławicach, Geopark Przedgórze Sudeckie (http://geoprodukt2017.geopark.org.pl). 